\title{
sciendo
}

DOI 10.2478/sbe-2020-0005

SBE no. 15(1) 2020

\section{ARE DETERMINANTS OF INTERNATIONAL FINANCIAL INTEGRATION IN THE EUROPEAN TRANSITION COUNTRIES DIFFERENT FROM POST-TRANSITION COUNTRIES?}

\author{
GANIĆ MEHMED \\ International University of Sarajevo, Bosnia and Herzegovina
}

\begin{abstract}
:
The paper seeks to empirically explore the variations and changes in the degree of International Financial Integration (IFI) between the European Transition countries and PostTransition countries between 2000 and 2016. The estimation of parameters was made using the Generalized Method of Moment (GMM) approach. The findings of the study reveal that European Post-Transition countries have relatively more developed financial systems compared to European Transition countries, where private credit market is still playing an overwhelmingly important role in a financial system while stock markets are in an early stage of development constituting a relatively small share of the financial system. Even though in Panel 3 there are significant control variables, our findings reveal that IFI in European transition countries are affected neither by stock market capitalization and private credit markets. Consequently, they can't be used in this stage of financial development for explanation of variations and changes in the degree of IFI.
\end{abstract}

Key words: international financial integration, European Transition and Post transition countries, Generalized Method of Moment (GMM) approach, Financial Market Development Indicators

\section{Introduction}

The interest in investigating financial integration (IFI) as an economic phenomenon increased in 1990s, and much research has been done on this topic since. Many of those studies also tested various economic variables that influence and accelerate the process of IFI. The main reason why European Transition and Post-Transition countries are chosen is due to their specific post-socialist development characterized by certain disparities in the levels of economic and financial development as well absence of research that aims to compare above mentioned two regions. Furthermore, the most of European Transition and Post-Transition countries share a common socialist legacy in a post-conflict stage of development and follows through similar, although not identical, processes of institutional transformation. This paper may shed light on the issue. 
The main aim of this paper is to empirically measure the variations in specific determinants affecting the level of IFIs and explore whether the indicators of domestic financial development affects the level IFI in the European Transition countries are different from Post-Transition countries. This is important, because some empirical studies suggested that impact of the indicators of domestic financial development on the level of IFIs may vary in accordance to the degree of domestic financial development and degree of total assets and liabilities divided by GDP as a measure of IFI.

Additionally, considering the ultimate goal of the study, we found that many studies employed panel data analysis, cross-sectional time-series and asset price model. Also, empirical models that explain the determinants of IFI in literature basically do not contain endogenous important economic and integration variables that affect IFI. Accordingly, the paper employs the Generalized Method of Moments (GMM) estimator, introduced by Arellano and Bond (1991), in order to emphasize certain econometric limitations and inconsistent estimates of the Ordinary Least Squares (OLS) earlier employed in the literature. The motivation for conducting this study stems from the fact that there is not enough empirical research in recent years related to the measurement of international financial integration in the Post-Transition countries, and even more so in some European Transition countries. The both regions share a common economic history and follow the similar transition models for the building of a market economy. Comparison of countries from the both regions is possible by considering the characteristics of macroeconomic indicators and a similar flow of deepening financial integration.

The contribution of this paper is seen in quantifying the relative importance of selected determinants of financial integration for the European Post-Transition countries and Transition countries. Additionally, the intention is that the econometric model presented in this paper can serve as a basis for future research that can be upgraded with additional variables to better explain new possibilities for deepening financial integration. Also, the findings of this study can be extended to transitioning countries since share many common features such as similar patterns of transition and their proximity to each other.

\section{Literature review}

Measuring levels of IFI can be a complex and tedious process. Recent conducted researches about measured levels of IFI used different financial variables as well as a set of control variables that are relevant to the phenomena they are investigating.

Herring (1994) found that the successful integration of financial markets is determined by both exogenous and endogenous determinants. His view has been especially useful for examining well known trends (financial liberalization, deregulation and lowering the cost of communications) that are associated with financial integration and how financial integration impacts economic or financial developments. Agenor (2001) extended the earlier argument by studying the economic benefits and costs of IFI employing a sample of 28 developing countries between 1980 and 1998. The findings of his research have shown some explanatory variables as follows: real GDP per capita, degree of trade openness have statistically significant impact on FDI inflows. 
The recent studies (Alfaro et al. 2004, Vo and Daly, 2007; Eichengreen, 2001; Aizenman and Noy, 2004; and Derado, 2009) have shown several statistically significant variables used in the process of explanation of IFI (trade openness, size of the market and the depth of the national financial markets). Alfaro et al. (2004) investigated the statistical impact of the well-developed financial markets on FDI inflows for 20 OECD countries and 51 non-OECD countries between 1975 and 1995. The results of the study found a statistically significant impact on well-developed financial markets on FDI inflows.

Additionally, Portes and Rey (1999) employed a gravity model for 14 countries between 1989 and 1996 in order to examine bilateral gross cross-border equity flows. Their findings indicated that GDP and market capitalization positively affect gross crossborder equity flows and transaction costs/ informational frictions negatively. It is also believed that the free movement of capital and a country's financial openness may result in greater macroeconomic policy discipline.

The study done by Lane and Milesi-Ferretti (2003) covered 18 member countries of the Organization for Economic Cooperation and Development (OECD) between 1978 and 2001 and examine a set of explanatory variables affecting foreign assets and liabilities (as a proxy variable for measurement of IFI) through panel regressions. The study found that some explanatory variables as trade openness, GDP per capita, tax policy and market capitalization may be used in explanations of variation in financial integration. These findings are not surprising given the analyzed sample of the OECD economies with welldeveloped financial systems. Also, a few years later Lane and Milesi-Ferretti, (2006) extended their database 'External Wealth of Nations' including the revision of the previous methodology, which contains information about the composition of international financial positions (IFS), including FDI, portfolio investment in shares, foreign debt and official reserve.

Other studies have primarily focused on assessing the determinants of international financial integration in the transition countries (Voronkova, 2004; Volz, 2004; Kučerová, 2009; and Derado, 2009; Rusek, 2005). Voronkova (2004) examined effects of IFI in some selected European countries (Czech Republic, Hungary, Poland, the United Kingdom, France, Germany, and the United States) by employing Gregory and Hansen's co integration approach. Her findings revealed the increasingly integrated the Central Eastern Europe (CEE) markets with the more general global market.

Volz (2004) examined financial integration and the financing of Small and mediumsized enterprises (SMEs) and access to finance in Central Eastern European and Baltic (CEB) countries, Commonwealth of Independent States (CIS) and the South East European (SEE). His findings suggest that the new EU member countries integrated into the single European capital market in an impressive way over the last decade. Shares of foreign banks in the market have increased significantly and that percentage of foreign banks' assets in total assets is much higher than the average in Western Europe.

In recent years, some economists have identified "drivers" or variables that affect and accelerate IFI. Among the most important determinants of IFI are the previously mentioned liberalization of the capital account, the level of financial development conditioned by openness to international markets, and the risk of a particular country (Vo and Daly, 2007) and the lack of ideal capital mobility (Von Furstenberg, 1998). 
More recently, Vo and Daly, (2007) empirically examined the drivers of IFI together with policy on capital controls and other components of financial structures between developing and developed countries. Between 1980 and 2003, the study covered developed (31 countries) and developing countries (47 countries) employing panel data estimation. The study estimates that some explanatory variables such as IMF capital control policy (coded as a dummy variable), high degrees of trade openness, a high value of domestic credit to private sector, and economic growth are shown as good predictors in explanations of international financial integration. Also, they found how industrialized or developed nations are far more and deeply integrated than developing countries. He also examined the effects of some macroeconomic factors as well as tax policy and found that there are statistically significant relationships between lower tax rates and inflows of foreign direct investment.

Kučerová (2009) aimed to measure the level of financial integration in eight of new EU members (the Czech Republic, Estonia, Hungary, Latvia, Lithuania, Poland, Slovakia, and Slovenia) by using panel regressions and harmonized data between 1994 and 2006. The study examined changes in a country's international investment position (foreign assets and liabilities was utilized as dependent variables). Her findings revealed that the explanatory variables such as real GDP per capita and foreign trade are shown as statistically significant in determination of further integration of financial market in new EU members.

Between 1995 and 2007, Derado (2009) explored the determinants of financial integration in eleven transition countries (Bulgaria, Croatia, Estonia, Hungary, Latvia, Lithuania, Poland, Romania, Slovakia and Slovenia) employing the Method of Least Squares. He found that trade openness, the "internationalization" of the banking sector, and formal relations with the EU have the strongest positive impact on the degree of financial integration, while variables GDP, population (POP) are as statistically insignificant in explaining the variance of the dependent variable.

As a general view of international financial integration, in their study Furceri et al. (2012) aimed to investigate the medium-term determinants of international investment positions for a sample of 70 advanced and emerging countries. The results indicate that capital flows are determined by domestic financial development, capital account openness, financial liberalization and improvements in institutional quality.

Recently, Alotaibi and Mishra (2014) employed external assets and liabilities positions as a depended variable in order to measure the level of international financial integration in seven countries of the Gulf Cooperation Council (GCC) between 1980 and 2010. They find that some variables as trade openness, financial openness and domestic credit have statistically significant impact on the level of international financial integration in the GCC region.

Some empirical evidence about the determinants of IFI provides controversial results. In their theoretical models, Garalia and Othmania (2015) explored the main determinants of international financial integration in the Middle East and North Africa (MENA) region between 2006 and 2012. Their study also found strong evidence that international financial integration (measured by external debt) is determined by the level of trade openness, high GDP, the exchange rate. However, the study finds a stock market 
capitalization, taxes, inflation, and levels of university education as statistically insignificant for determining international financial integration in the MENA region. Also, Daly and Vo (2007) finds a domestic stock market activity as insignificant determinant and stock market capitalization as significant determinant in explaining of IFI for the sample of 79 countries between 1980 and 2003.

The econometric analysis and findings show that there is no clear consensus of all important determinants of FDI flows. Many less advanced countries, such as European transition countries are much less analyzed than the successful European post transition countries. Unlike similar empirical studies, this paper includes and compares the both groups of countries using new and longer time series data from 2000 - 2016. A large amount of research on the determinants of international financial integration has been conducted in countries that have not experienced a transition from a socialist oriented economy to a market oriented economy (Vo and Daly, 2007; Alfaro et al. 2004, Vo and Daly, 2007 Eichengreen, 2001, Aizenman and Noy, 2004). Accordingly, this paper explores the determinants of IFI throughout a sample of European transition and post transition countries that share a similar model of economic development.

\section{Methodology and data}

The methodologies used in the literature to assess the impact of selected financial and economic variables on financial integration have become more complex. The methodology used in this study is a modified version of the models developed initially by Lane and Milesi-Ferretti (2006). All transition countries are divided into two groups based on the criterion whether they joined to EU or on the road to EU. In the group of the European Post Transition countries have included some selected new members of the European Union (which joined EU: 2004, 2007 or 2013) because they successfully completed the process of political and economic transition by joining the EU. On the other hand, other European transitional countries are considered less successful (EU candidates or potential EU candidates) and are still in the transition phase. The empirical part of this study employs a set of relevant indicators related to the domestic financial structure of selected European Post Transition countries which joined the EU (Bulgaria, Croatia, Romania, Slovenia, Czech Republic, Poland and Slovakia) and European Transition countries (Albania, Bosnia and Herzegovina, Former Yugoslav Republic of Macedonia, Serbia, Montenegro and Turkey) on an annual basis between 2000 and 2016.

The econometric model is in line with the previous research and examines a set of explanatory variables affecting IFI. Based on the pioneering work of Lane and MilesiFerretti (2006) in this study an international financial integration as the sum of total assets and liabilities divided by GDP is used as a proxy variable. The data are obtained from the extended version of Lane \& Milesi-Ferretti, 2007 database.

The data used in the study were sourced from several databases. The data for the variable DOMCREDIT (domestic credit to private sector as a percentage of GDP) was obtained from the World Bank - World Development Indicators while for the variable VAFATVA (Value added financial activities as a percentage of total value added) data are sourced from EUROSTAT. Data for the variable KAOPEN (Capital Openness) was 
sourced from Chinn-Ito index based on the IMF's Annual Report on Exchange Arrangements and Exchange Restrictions (AREAER) while the variable StkCap (Stock market capitalization as percentage of GDP) was sourced from The Global Financial Development Database published by the World Bank while corporate tax rate (TAXRATE) data was sourced from KPMG database. The variable FINFREED (Financial Freedom) is proxied to measure a country's banking efficiency and independence from government control and interference in the financial sector. In our study, the variable based on data published by the Heritage Foundation (Index of Financial Freedom).

The econometric model is in line with previous researches done by Vo, and Daly (2007) and Lane and Milesi-Ferretti (2003; 2006) and employs the several control variables in a model as follows: VAFATVA, FINFREED and tax rate.

A dynamic panel model was chosen because it was much less employed in the previous research about financial integration and because this estimator is suitable for the analysis of a linear relationship, in which the dependent variable is dynamic, that is, dependent on its own past values, and when the independent variables are not strictly exogenous. It takes into account the specificity of each observation unit and allows heteroskedasticity and autocorrelation within the observation units, but not among them (Roodman, 2006). Moreover, due to the dynamic nature of financial integration as dependent variables and the characteristics of sample, the estimation of parameters was made using the Generalized Method of Moment (GMM) approach with the verification of Sargan test statistics and Arellano-Bond tests. It is run to solve possible issues with the heteroskedasticity and reverse causality.

Bearing in mind that there no available data for every country for all years, an unbalanced panel model will be used to evaluate the appropriate models.

The above mentioned model can be expressed as follows:

$\mathrm{Y}_{\mathrm{it}}=\mu+\delta \mathrm{y}_{\mathrm{i}, \mathrm{t}-1}+\beta_{\mathrm{i}} \mathrm{x}_{\mathrm{itK}}+\mathrm{v}_{\mathrm{i}}+\mathrm{u}_{\mathrm{it}}$

Where index $i=1 \ldots 13$ symbolizes selected country of the SEE region and $t=$ 2000-2016 symbolizes time/ different years, $Y_{i t}$ denotes the value of the dependent variable as sum of portfolio equity assets and liabilities and foreign direct investment assets and liabilities by GDP $\mathrm{i}$ in the period $\mathrm{t}$, the parameter $\mu$ is a constant member, $\delta$ represent the scalar, $\mathrm{y}_{\mathrm{i}, \mathrm{t}-1}$ is a dependent variable (for the same country) with time lag of one year, $\mathrm{x}_{\mathrm{it} 1, \ldots,} \mathrm{x}_{\mathrm{itK}}$ are $\mathrm{K}$ explanatory variables (IFII(-1)= First lag of IFI, StkCap, DCREDIT, VAFATVA, KAOPEN, FINFREED, TAX Rate) for a country $i$ in period $t, v$ is fixed effect or random effects for the observation unit, and $u_{i t}$ is the usual disturbance term. The assumption of the model is that all the variables $x_{i t}$ are strictly exogenous in the sense that assumed to be uncorrelated with any $\mathrm{u}_{\mathrm{it}}$.

The short overview of the literature review provided some information about the statistical significance of standard economic and financial indicators at the level of international financial integration (Agenor, 2001; Lane and Milesi-Ferretti, 2003; Vo, 2005; Xuân Vinh, 2005; and others). The empirical analysis of the relationship between the expected direction of the dependent and independent variables is based on the abovementioned assumptions.

The variable VAFATVA is included as a proxy variable for measuring levels of financial transformations or financialization. The increasing process of financial 
transformations of national economies and the rise of financial assets and financial activities in terms to the rest of economy leads to rise of cross bordering flows and international financial integration (Karwowski and Stockhammer, 2016). It is expected that this variable has a positive impact on the level of international financial integration.

Inclusion of Financial Freedom variable is based on evidence of previous research (La Porta, 1997; Obsfield, 1994; Kalemli-Ozean et al., 2010) about the relationship between capital mobility and IFI in the host economies. A positive impact of Financial Freedom variable on financial integration can be expected.

A tax policy is another factor affecting levels of international financial integration. More specifically, low corporate tax rates along with other tax benefit encourage the transfer of financial assets. In this case, a lower tax rate and lower tax burdens are associated with an increase in cross-border financial transactions that ultimately attracts foreign companies and international financial intermediaries (Vo and Daly 2007). Consequently, in the case of the variable of national tax policy, it is expected to have a positive impact on the degree of international financial integration.

The Financial Market Development Indicators (Stock market capitalization and the ratio of domestic credit to GDP) are crucial for proving the links between the financial market development and international financial integration. These variables were chosen to explain some characteristics of the countries' market structure.

The variable KaOpen (Capital Openness) is used to measure a country's degree of capital account openness and the country's level of financial liberalization. Previous studies (Vo and Daly, 2007, Furceri et al., 2012 and Alotaibi and Mishra, 2014) have shown that high financial sector liberalization and the free mobility of capital positively affect the degree of international financial integration. The expected relationship between these variables and international financial integration is a positive. This suggests that a country that possesses a higher level of openness of the capital account also is inclined to be more financially integrated at the international level.

The following variables have been shown to have a significant impact on the level of international financial integration: the development of the domestic financial system ((Lane and Milesi-Ferretti (2003), Portes and Rey (1999), Vo and Daly (2007), Adam et.al (2002) and others)) measured by the size of the stock market stock capitalization (StkCap), and the ratio of domestic credit to GDP (DCREDIT). The aforementioned variables are included in our model and are expected to be positive indicators. Recent empirical research supports the view that the development of the financial sector amplifies the growth of international financial integration (Furceri et al., 2012 and Alotaibi and Mishra, 2014). More developed financial markets attract foreign investors who want to diversify their portfolio and thus acts as a stimulant financial integration.

Our research tries to test the following hypothesis:

$\mathrm{H} 1$ : Hypothesis for each variable is that the each explanatory variable has a significant impact on financial integration.

$\mathrm{HO}$ : Hypothesis for each variable is that the each explanatory variable has no significant impact on financial integration. 


\section{Findings and discussion}

Table 1 below provides the main findings of descriptive statistics of dependent and independent variables (mean, standard deviations and coefficient of variations) by panels of countries. In the period between 2000 and 2016 the lowest level of international financial integration (0.08) was found in Bosnia and Herzegovina (2000) while the highest (3.82) in Montenegro (2013). The mean of financial integration, measured by IFI for European post transition countries in the sample is 1.66 while for European transition countries is 1.37 . The coefficient of variations for European transition countries is higher (0.83) than European post transition countries (0.72) suggesting that they are more volatile than European post transition countries.

Also, based on the results of descriptive statistics we found that the mean value of financialization for the European post transition countries amounted to 4.46, while for European transition countries was 3.30, and for the full sample 3.96. In terms of ratio of stock market capitalization to GDP, the mean value for Full sample, European post transition countries and European transition countries was 22.6, 19.87, and $27.20 \%$ of GDP respectfully. The high values of coefficient variations for the all three panels reveal that there is significant volatility among the countries in terms of development of stock markets. For example, the maximum value of ratio of stock market capitalization to GDP recorded in Montenegro (86.64\% of GDP in 2012) while the lowest rate of stock market capitalization to GDP $(0.20 \%$ of GDP) was recorded in Macedonia (2000).

The mean value of domestic credit to GDP for Full sample, European post transition countries and European transition was 41.11, 44.27 and $37.27 \%$ in the reference period. The lowest rate of domestic credit to GDP $(0.18 \%$ of GDP) was recorded in Slovenia (2004), while the highest was found in Montenegro (2008) with $86.52 \%$ of GDP.

Table 1: Summary Statistics by panels of countries

\begin{tabular}{|c|c|c|c|c|c|c|c|c|c|}
\hline & \multicolumn{3}{|c|}{ Full sample } & \multicolumn{3}{|c|}{ European Post Transition countries } & \multicolumn{3}{|c|}{ European Transition countries } \\
\hline Variable & Mean & Std. Dev. & CV & Mean & Std. Dev. & CV & Mean & Std. Dev. & $\mathrm{CV}$ \\
\hline IFI & 1.526 & 0.6155 & 0.403 & 1.6558 & 0.474106 & 0.286322 & 1.374473 & 0.721913 & 0.525229 \\
\hline STKCAP & 22.60 & 18.2156 & 0.805 & 19.876 & 14.46226 & 0.727615 & 27.20948 & 22.60709 & 0.830853 \\
\hline DCREDIT & 41.11 & 17.7572 & 0.431 & 44.272 & 17.77072 & 0.401395 & 37.27179 & 17.05368 & 0.457549 \\
\hline KAOPEN & 0.557 & 0.30763 & 0.552 & 0.7067 & 0.264928 & 0.37483 & 0.350227 & 0.234565 & 0.669752 \\
\hline VAFATVA & 3.968 & 1.37039 & 0.345 & 4.4614 & 1.387512 & 0.311003 & 3.308778 & 1.033086 & 0.312226 \\
\hline FinFREED & 58.87 & 13.442 & 0.228 & 62.184 & 13.47689 & 0.216723 & 54.60217 & 12.19395 & 0.223324 \\
\hline
\end{tabular}




\begin{tabular}{|l|l|l|l|l|l|l|l|l|l|}
\hline TAXRATE & 17.40 & 6.08339 & 0.350 & 19.887 & 4.690601 & 0.235854 & 14.45 & 6.24803 & 0.43239 \\
\hline
\end{tabular}

Source: The Author's Calculations

It is interesting that degree of capital account liberalization in the European Transition countries was 0.35 with a high coefficient of variation (0.67) while in the European Post Transition countries was 0.70 with a coefficient of variation of 0.37 . The highest value a degree of capital account liberalization of 1 were found in Romania, Czech Republic, Bulgaria, Slovenia and Bosnia and Herzegovina.

Also, the selected variables employed in our econometric models were checked for multicollinearity. The findings from the testing of variables may be found in correlation matrix (Table 2). Following Gujarat and Porter's (2008) recommendations, the serious problem of multicollinearity exists if the correlation between a pair of explanatory variables exceeds the value of 0.8 . In our case, the highest coefficient of correlation is 0.7 between the variable "DOMCREDIT" and "IFI ".

Table 2: Correlation Matrix

\begin{tabular}{|l|l|l|l|l|l|l|l|}
\hline & IFI & KAOPEN & FINFRE & TAX RATE & StkCap & DCredit & VAFATVA \\
\hline IFI & 1.0000 & & & & & & \\
\hline KAOPEN & 0.4668 & 1.000 & & & & & \\
\hline FINFRE & 0.2570 & 0.3275 & 1.000 & & & & \\
\hline TAX RATE & -0.3196 & -0.1375 & 0.0804 & 1.000 & & & \\
\hline StkCap & 0.1018 & 0.1604 & 0.0264 & -0.0447 & 1.000 & & \\
\hline DCredit & 0.7000 & 0.4438 & 0.0658 & -0.3591 & 0.4228 & 1.000 & \\
\hline VAFATVA & 0.6101 & 0.4339 & 0.1139 & -0.2672 & 0.3900 & 0.6869 & 1.000 \\
\hline
\end{tabular}

Source: The Author's Calculations

Additionally, the (non) existence of multicollinearity was examined by using standard indicators as the Variance Inflation Factor (VIF). Consequently, based on the Variance Inflation Factor (mean of VIF is 1.56, Appendix 2) it can be concluded that multicolinearity is not likely an issue in regard to the observed groups of explanatory variables used in this model.

Before analyzing the model's findings, some diagnostic tests were conducted to examine the validity of the model. In a dynamic panel analysis, Sargan's test and diagnostic tests on autocorrelation were run to examine differences in residual deviations established by Arellano and Bond (1991). The null hypothesis of the Sargan's test is that the selected instrument variables are uncorrelated with the residuals.

As shown in Table 3, the p-value of the Sargan's test statistic confirms the validity of the selected variables in an econometric model. Moreover, since the estimated $p$ value of AR (2) test is 0.9476 , absence of second-order serial correlation in the error term is rejected. It confirms that the model is well specified and meet specific requirement for instrument validity.

The table 3 summarizes the estimates for the full sample and separately for European Post-Transition countries and Transition countries. Three Panel models in columns (1), (2), and (3) fit well. Additionally, the whole sample was divided into two 
subpanels, Panel 2: European Transition and Panel 3: Post- Transition countries to explore whether there is difference between the main determinants of IFI in the European Transition countries and from Post-Transition countries.

The value of IFII(-1) in Panel 2 (-0.2695229) and Panel 3 (-0.5044055), implies that international financial integration are corrected by 2.6 and $5 \%$ each year.

Panel 1 shows that international financial integration is statistically significant and strongest influenced by the variables as follows: StkCap, DCREDIT, VAFATVA and FINFREED with statistical significance at $1 \%$. The coefficients for the variables DCREDIT, VAFATVA and FINFREED have anticipated signs and a positive effect on promoting the growth of financial integration. It is in the line with some previous conducted studies (La Porta, 1997; Kalemli-Ozean et al., 2010, Karwowski and Stockhammer, 2016, Lane and Milesi-Ferretti (2003), Portes and Rey (1999), Vo and Daly (2007)).

Further, the findings of Panel 1 reveal that a higher level of private credit to GDP significantly increases the level of financial integration. In Panel 1 and panel 2, our estimates suggest that a one percentage increase in domestic credit, ceteris paribus will increase the level of international financial integration by 1.6 and $1.43 \%$ respectfully; a one percentage increase in stock market capitalization will decrease level of international financial integration by 1.08 and $1.04 \%$ respectfully.

More interestingly, the findings of the study reveal that stock market capitalization for the whole sample of countries as well as in Panel 2 negatively affects international financial integration although for Panel 3 , the variable is shown as statistical insignificant.

Table 3: GMM estimates

\begin{tabular}{|c|c|c|c|}
\hline Explanatory variables & Panel 1: Full Data & $\begin{array}{l}\text { Panel 2: EU post- } \\
\text { transition }\end{array}$ & $\begin{array}{l}\text { Panel 3: EU pre- } \\
\text { transition }\end{array}$ \\
\hline IFII(-1) & $\begin{array}{l}-.0538352 \\
{[-0.97]}\end{array}$ & $\begin{array}{l}-.2695229 \\
{[-3.01]^{\star * \star}}\end{array}$ & $\begin{array}{r}-.5044055 \\
{[-4.26]^{\star * *}}\end{array}$ \\
\hline StkCap & $\begin{array}{c}-.0108188 \\
{[-16.51]^{\star * *}}\end{array}$ & $\begin{array}{ll}-.0104493 & {[-} \\
3.50]^{* *} & \end{array}$ & $\begin{array}{l}-.0027144 \\
{[-0.62]}\end{array}$ \\
\hline \multirow{2}{*}{ DCREDIT } & .0165051 & .0148803 & -.0127763 \\
\hline & {$[18.82]^{* * *}$} & {$[16.63]^{* * *}$} & {$[-0.49]$} \\
\hline \multirow{2}{*}{ KAOPEN } & -.0596415 & .0389144 & -.9286373 \\
\hline & {$[-1.45]$} & {$[0.47]$} & {$[-3.99]^{\star * *}$} \\
\hline VAFATVA & $\begin{array}{l}.1008849 \\
{[9.24]^{\star \star \star}}\end{array}$ & $\begin{array}{l}.1076346 \\
{[3.87]^{\star * *}}\end{array}$ & $\begin{array}{l}.1403978 \\
{[2.20]^{* *}}\end{array}$ \\
\hline FINFREED & $\begin{array}{r}.009241 \\
{[13.19]^{* * *}}\end{array}$ & $\begin{array}{l}.0107709 \\
{[5.11]^{* * *}}\end{array}$ & $\begin{array}{l}.0112231 \\
{[4.34]^{* * *}}\end{array}$ \\
\hline \multirow{2}{*}{ TAX RATE } & .0039605 & .0107709 & -.0208821 \\
\hline & {$[1.02]$} & {$[0.25]$} & {$[-2.23]^{\star *}$} \\
\hline AR (2) test & $\begin{array}{l}.06578 \\
{[0.9476]}\end{array}$ & $\begin{array}{l}.67494 \\
{[0.4997]}\end{array}$ & $\begin{array}{l}-.82214 \\
{[0.4110]}\end{array}$ \\
\hline Sargan test ( $p$-value) & $\begin{array}{l}14.63059 \\
{[1.00]}\end{array}$ & $\begin{array}{l}12.81335 \\
{[0.9998]}\end{array}$ & $\begin{array}{l}4.934749 \\
{[0.9979]}\end{array}$ \\
\hline
\end{tabular}

The t-statistics are shown in parentheses [ ], ${ }^{* * *},{ }^{* *}$ and ${ }^{*}$, and are statistically significant at $1 \%, 5 \%$ and $10 \%$ levels, respectively

Source: The Author's Calculations 
In Panel 1 and Panel 2, a stock market capitalization is still relatively low given the capacity of financial markets in these countries. Accordingly, its effect on IFI is statistically significant, but a negative, suggesting that stock market capitalization has a negative effect on IFI. The possible potential causes may be doubled. Firstly, European Transition and Post-Transition countries basically achieve lower values of international assets and liabilities, mainly due to the underdeveloped financial sector. Secondly, due to the lack of a developed financial market and non-banking financial institutions, both groups of countries generally don't achieve liquidity levels and market capitalization comparable to those of the developed countries. For example, in Panel 3 stock market capitalization has a negative sign and statistically insignificant impact on IFI. It can be additionally explained by the fact that small size of the financial markets with a small volume of transaction compared to the size of economies of European Transition countries makes them less attractive for investiture (Rusek, 2005). The stock market development in all European Transition countries was driven by the privatization process but no need for private financing. As the process of privatization is almost completed in all countries that is a reason for statistically insignificant impact on IFI Also, stock market capitalization in European Transition countries vary substantially from 4 to $35 \%$ of GDP with some exception as Montenegro between 75 and $85 \%$ of its GDP.

If we follow some recent studies (Lane and Milesi-Ferretti 2003, Vo \& Daly, 2007, Furceri et al., 2012 and Alotaibi and Mishra, 2014) it can be concluded that if any country from the sample has more or less developed financial market, higher or lower level of financial deepening, it may induce more or less integration of the country in international financial flows.

In Panel 1 and Panel 2, the study couldn't find any statistical significant evidence between KAOPEN and Tax rate with international financial integration. This can be explained by the fact that in some of most of the analyzed European transition countries a country's taxation policy is still disincentive. Looking at individual countries, tax burdens in Croatia (20\%), Czech Republic (19\%), Slovenia (17\%), Slovakia (22\%) and Poland (19\%) doesn't effect on attracting capital and deeper financial integration.

Also, in the case of capital openness a mean value for European post transition countries is a relatively high (0.70) and there is no more room for further increasing of capital openness to affect international financial integration. This suggests that greater capital openness does not always mean degree of financial integration as well as that financial integration cannot be achieved only by administrative measures and regulatory changes.

Regarding Panel 2, our findings are similar to those of the full panel (Panel 1). The coefficients for the most of variables have the same sign and are statistically significant by confirming the rationality of the selection of variables. For example, in Panel 2 the variables DCREDIT, VAFATVA and FINFREED continue to affect IFI significantly at $1 \%$, as in Panel 1. One may conclude that private credit market exerts strong evidence as the main driver of international financial integration in the Panel 1 and Panel.

In Panel 3 the findings are mixed by considering different empirical studies. Seen as in Panel 3 there are some differences in the degree of influence of set control variables for determination of financial integration in European Post- Transition countries as 
VAFATVA, FINFREED, TAXRATE and KAOPEN. Though the variable KAOPEN is statistically significant at $5 \%$, but has a negative sign. This result may not be surprising. The mean value for capita openness in the European transition countries is very low (0.35) and two times less than in the European post transition countries. It is not with our expectations and previous studies done by Vo and Daly, 2007, Furceri et al., 2012 and Alotaibi and Mishra, 2014. For example, a one percentage increase in KAOPEN will decrease the level of international financial integration by $0.92 \%$. Additionally, our findings reveal that IFI in Panel 3 are affected neither by stock market capitalization and DCREDIT.

The findings also provide strong evidence that the variable of financial transformation or financialization has a statistical significance and a positive impact on the determination of financial integration. It is in the line with a study done by Karwowski and Stockhammer (2016). This shows that the countries of the region have a growing share of the financial services sector relative to the rest of the economy and induce more integration of the country in international financial flows.

\section{Conclusion}

This study aimed to explain variations in international financial integration of the European Post- Transition and Transition countries, including Turkey, which have strong historical, cultural, and economic links with Transition countries as well as an EU candidate status. To prove or disprove the hypothesis, we first presented a set of empirical studies that analyzed the influence of selected determinants on the growth of financial integration. Although the both regions increased modestly the level of international integration in the last two decades, we found in general that the European Post- Transition countries as a group have a higher degree of international financial integration than European Transition countries. It is consistent with our prior expectations.

However, the difference and gap continues to be narrowing. Also, the findings of the study reveal that determinants of financial integration are not as relevant to the European Post- Transition countries as to European Transition countries. This is because European Post- Transition countries with relatively more developed financial systems, where credit market is still playing an overwhelmingly important role in a financial system while stock markets are in an early stage of development constituting a relatively small share of the financial system.

The econometric model has proven that international financial integration is positively related with domestic credit growth and negatively with the development of capital markets in Panel 1 and Panel 2. The private credit growth can be used in explaining variations in the degree of international financial integration. Likewise, it can be concluded that capital openness and tax rate in the observed sample of countries is a limiting factor for the deepening of financial integration in Panel 1 and Panel 2. Empirically, it has shown that a taxation policy is less important in explaining the growing financial integration of the European post transition countries.

The stability of most economies has been achieved already in the early years of transition, but international financial integration is still at an unsatisfactory level with some constraints. Insufficient level of international financial integration in transition countries can 
be explained by some constrained as: insufficient participation of foreign active in the total assets of the banking sector, high tax burdens in some countries, but also insufficient growth of economies.

Compared to the previous one, capital markets in European transition countries are still underdeveloped, in the infant stage of development, characterized by low market capitalization, low liquidity, and a lack the breadth and depth in financial markets more generally. One of the reasons is the fact that the region as a whole lags behind the standards of financial integration in advanced industrial countries. In Panel 3, the study found that the level of stock market capitalization and private credit growth are a very low and doesn't affect significantly on international financial integration. They cannot be used in this stage of financial development for explanation of variations in the degree of IFI.

Our findings thus suggest that financial integration does not appear spontaneously, only as a consequence of the abolition of capital barriers. These results indicate that it is possible to conclude that countries with well developed domestic financial systems (higher the ratio of domestic credit to GDP, higher degree of financialization and financial freedom, lower corporate tax rates) tend to be more financially integrated. These research findings have important implications for policy makers to follow a policy on deepening financial markets and stimulate financial development as seems to be justified.

\section{References}

Adam, K., Jappelli T., Menichini A. M., Padula M., and M. Pagano (2002), Analyse, Compare, and Apply Alternative Indicators and Monitoring Methodologies to Measure the Evolution of Capital Market Integration in the European Union, Report to the European Commission.

Agenor, P.R. (2001). Benefits and Costs of International Financial Integration: Theory and Facts, Policy Research Working Paper 2699, World Bank Institute. Retrieved from: http://documents.worldbank.org/curated/en/240401468766831345/pdf/multiOpage.pdf

Aizenman, J and Noy, I. (2006). FDI and trade - two-way linkages? Quarterly Review of Economics and Finance, 46 (3), 317-337.

Alfaro, L, Chandab, A, Kalemli-Ozcancebnem, S and Sayek, S. (2004). FDI and economic growth: the role of local financial markets, Journal of International Economics, 64 (1), 89 - 112, Retrieved from: http://www.people.hbs.edu/lalfaro/fdijieoct2004.pdf

Alotaibi, R. and Mishra, A. (2014). Determinants of International Financial Integration of GCC Markets, in Mohamed E. H. A., Sabri B., Duc K. N., Emerging Markets and the Global Economy: A handbook, : Elsevier, pp.749-771.

Arellano, M., and Bond, S. (1991). Some tests of specification for panel data: Monte Carlo evidence and an application to employment equations. Review of Economic Studies, 58(194), 277-297

Baltagi, B. H. (2008). Econometric Analysis of Panel data, 4th ed., Hoboken, N.J.: John Wiley and Sons,

Bond, S. R., (2002). Dynamic panel data models: a guide to micro data methods and practice. Portuguese Economic Journal, 1(2), pp. 141-162. doi: 10.1007/s10258-002-0009-9

Daly, K. J. and Vo, V.X, (2007). Quantifying the drivers of international financial integration, Journal of Investment Strategy, Volume 2, Number 1, 2007.

Derado, D. (2009). Financijska integracija i financijska kriza: Hrvatska na putu prema ekonomskoj $i$ monetarnoj uniji, Financijska teorija i praksa, 33 (3), 303-333. Retrieved from: http://www.ijf.hr/FTP/2009/3/derado.pdf. 
Eichengreen, B. (2001). Capital Account Liberalization: What Do the Cross-Studies Tell Us?, World Bank Economic Review, October 2001; 15: 341-65.

Furceri, D., Guichard, S. and Rusticelli, E. (2012). Medium-Term Determinants Of International Investment Positions: The Role Of Structural Policies, Journal of International Commerce, Economics and Policy (JICEP), 3 (2), 1-32.

Garalia, W. and Othmania, S. (2015). The determinants of international financial integration in the MENA area, Procedia Economics and Finance, 26, 535 - 541. Retrieved from: http://ac.elscdn.com/S221256711500951X/1-s2.0-S221256711500951X-main.pdf?_

Herring, R. J. (1994). International Financial Integration: The Continuing Process, Wharton School Financial Institutions Center Paper 94 - 23, Philadelphia: University of Pennsylvania.

Karwowski, E and Stockhammer, E. (2016). Financialisation in Emerging Economies: A Systematic Overview and Comparison with Anglo-Saxon Economies, Post Keynesian Economics Study Group, Working Paper 1616.

Kučerová, Z. (2009). Measuring Financial Integration in Central Europe through International Investment Positions, Eastern European Economics, 47 (4), 25-41 Retrieved from: http://www.jstor.org/stable/pdf/27740129.pdf

Lane, P. R. and Milesi-Ferretti, G. M. (2003). International financial Integration, Discussion Paper N 3, Institute for International Integration Studies and Economics Department, TCD and CEPR,

Lane, P. R. and Milesi-Ferretti, G. M. (2006). The External Wealth of Nations Mark II: Revised and Extended Estimates of Foreign Assets and Liabilities, 1970-2004, IMF Working Paper 06/69, Washington: International Monetary Fund.

La Porta, R., Lopez-De-Silanes, F., Shleifer, A., and Vishny, R. (1997). The Legal Determinant of External Finance. Journal of Finance, Vol. 52, No. 3: 1131-1150.

Portes, R. and Rey, H. (1999). The Determinants of Cross-Border Equity Flows, National Bureau of Economic Research Working Paper, no. 7336. Retrieved from: http://www.nber.org/papers/w7336

Roodman, D. (2006). How to Do xtabond2: An Introduction to "Difference" and "system" GMM in Stata" Working Paper Number 103, Center for Global Development.

Rusek, A. (2005). Financial Integration and the New EU Member Countries: Challenges and Dilemmas. PRAGUE ECONOMIC PAPERS, 1, 2005. DOI: 10.18267/j.pep.250.

Vo, X. V. and Daly, K. J. (2004). The relationship between net private capital flows and economic growth in emerging Asian economies. International Business Research Conference: Melbourne, Vic.,

Vo, X. V. and Daly, K. J. (2007). Determinants of international financial integration. (R. P. C. Leal, Ed.), Rio de Janerio, Coppead Graduate School of Business: Federal University of Rio de Janerio-Global Finance Conference

Volz, U. (2004). European financial integration and the financing of local businesses in the new EU member states, Working Paper No. 89., London, UK: European Bank for Reconstruction and Development.

Von Furstenberg, G. M. (1998). From Worldwide Capital Mobility to International Financial Integration: A Review Essay, Open Economies Review, 9 (1), 53-89.

Voronkova, S. (2004). Equity Market Integration in Central European Emerging Markets: A Co integration Analysis with Shifting Regimes, International Review of Financial Analysis, 13 (5), pp. 633-647. 
Studies in Business and Economics no. 15(1)/2020

\section{Appendix 1}

Table Summary of variables used in regression model

\begin{tabular}{|l|l|l|}
\hline \multicolumn{1}{|c|}{ Variable } & \multicolumn{1}{|c|}{ Measurement } & \multicolumn{1}{c|}{ Source } \\
\hline IFI & $\begin{array}{l}\text { International financial integration measured by } \\
\text { foreign assets and foreign liabilities divided by } \\
\text { GDP }\end{array}$ & $\begin{array}{l}\text { Lane and Milesi-Ferretti, "The } \\
\text { External Wealth of Nations Mark } \\
\text { II" }\end{array}$ \\
\hline STKCAP & The ratio of stock market capitalization to GDP & $\begin{array}{l}\text { The Global Financial Development } \\
\text { Database (the World Bank) }\end{array}$ \\
\hline KAOPEN & $\begin{array}{l}\text { Capital Openness-the Chinn-Ito index is } \\
\text { normalized between zero and one. }\end{array}$ & Chinn-Ito \\
\hline DCREDIT & The ratio of domestic credit to GDP & $\begin{array}{l}\text { World Bank's World Development } \\
\text { Indicators }\end{array}$ \\
\hline TAXRATE & The Corporate Tax Rate & $\begin{array}{l}\text { KPMG } \\
\text { total value added }\end{array}$ \\
VAFATVA & $\begin{array}{l}\text { Financial freedom, measure a country's banking } \\
\text { efficiency and independence from government } \\
\text { control and interference in the financial sector }\end{array}$ & $\begin{array}{l}\text { Heritage Foundation, (Index of } \\
\text { Financial Freedom) }\end{array}$ \\
\hline
\end{tabular}

Appendix 2 VIF test

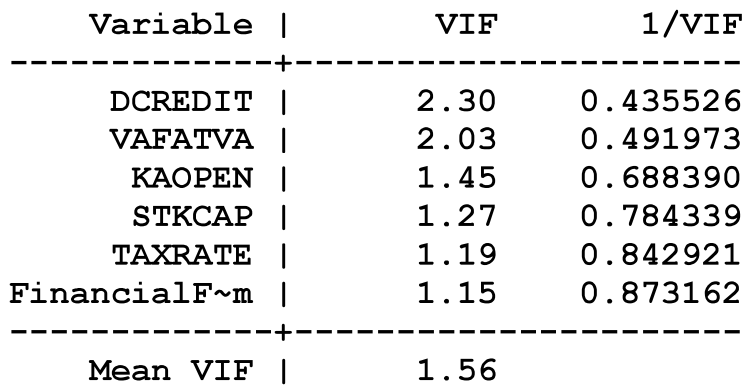

